\title{
Coastal erosion
}

\begin{abstract}
Most of the World's shorelines are retreating. An erosion crisis is at hand because development in the endangered zone is increasing, and halting shoreline erosion can be very costly in economic and environmental terms. The shoreline erosion problem is "solved" by (1) hard shoreline stabilization, for example, seawalls; (2) soft shoreline stabilization, for example, beach replenishment; and (3) building relocation. Because of concern for preservation of recreational beaches, the use of hard stabilization, that is, seawalls, is sometimes being restricted.
\end{abstract}

\section{Introduction}

Coastal erosion is a major problem for developed shoreline everywhere in the world. Where sufficient capital exists, as in Japan, massive structures are built and maintained to hold back the forces of the sea. Where poverty is the norm, as in much of Africa, buildings tumble into the sea routinely, or they are moved back step by step, apace with shoreline retreat.

In the United States, the coastal erosion problem annually becomes more critical as large numbers of wealthy, influential people crowd against a retreating shoreline. In the Mississippi Delta, salt marsh is disappearing at an alarming rate owing to a combination of erosion, drowning, and the impact of man on the marsh. Here endangered buildings are not the problem, but land loss is.

The coastal erosion crisis is man made, in a sense, because if no one lived next to the shore, there would be no problem. Furthermore, man is immeasurably compounding the problem by actually increasing rates of erosion in a number of ways. But, examination of the world's barrier-island shorelines indicates that fundamental and purely natural global changes are also afoot. Many barrier islands are regressive in nature, indicating a seaward accretion of the island over the last 3,000 to 4,000 $\mathrm{yr}$. Most regressive barrier islands (for examples, Galveston Island, Texas, and Bogue Banks, North Carolina), however, are now eroding on both the ocean and lagoon sides. Clearly within the last few millennia a profound change has taken place, and shoreline retreat has replaced shoreline growth.

The role of man in coastal retreat ranges from global to local. Production of excess carbon dioxide is leading to greenhouse-effect sea-level rise and accelerated erosion. Construction of dams reduces the supply of sand to the beaches and leads to accelerated erosion. The armoring of the shoreline to prevent erosion often leads to more erosion rather than less. And increasingly there is widespread concern that efforts to save manmade structures along shorefronts lead to the destruction of recreational beaches that were often the reason the buildings were built to begin with.

United States erosion data have been summarized recently by Dolan and others, 1985. A broad discussion of the U.S. problem along with methodology, political implications, and costs for mitigation is furnished by the National Research Council (1990).

Bird (1985) in a global review of coastal changes, emphasizes the need to consider the different types of coasts separately in study of the rates and mechanics of erosion. Bird's review highlights the fact that the coastal erosion problem is truly global in its scope.

Shoreline erosion is best termed shoreline retreat. This is because the beach, the most visible and valuable part of most shorelines, is not really eroding; it is simply changing its position in space. This fact can be expressed as a shoreline truth that is critical for the understanding of the shorelines by both the public and the scientific community. This truth is: shoreline erosion does no damage to the recreational beach.

This truth is partially illustrated by the photo of the Morris Island Lighthouse seaward of Morris Island, South Carolina (fig. 1). During World War II the lighthouse was on land beside a large U.S. Coast Guard Station adjacent to a broad sandy beach. Now the broad sand beach is $400 \mathrm{~m}$ east of its World-War-II position, still a broad beach.

A second truth, illustrated by figs. 2 and 3 , is that there is no shoreline erosion problem until a man-made structure is threatened. Figure 2 shows a log-strewn beach on St. Catherine's Island, Georgia. Clearly the shoreline here is retreating at a rapid rate. But this is a shoreline with no shorefront development, so no one is complaining or asking for government aid. Figure 3 shows a log-strewn beach on a tropical rain-forest-covered barrier island on the Pacific coast of Colombia, South America. Clearly an erosion problem does exist here as a building is in imminent danger of loss from shoreline erosion.

\section{Causes of shoreline erosion}

Beaches can be viewed as systems in dynamic equilibrium. The equilibrium involves 4 factors: (1) the level of the sea, (2) wave and tidal energy, (3) beach sediment supply, and (4) position in space.

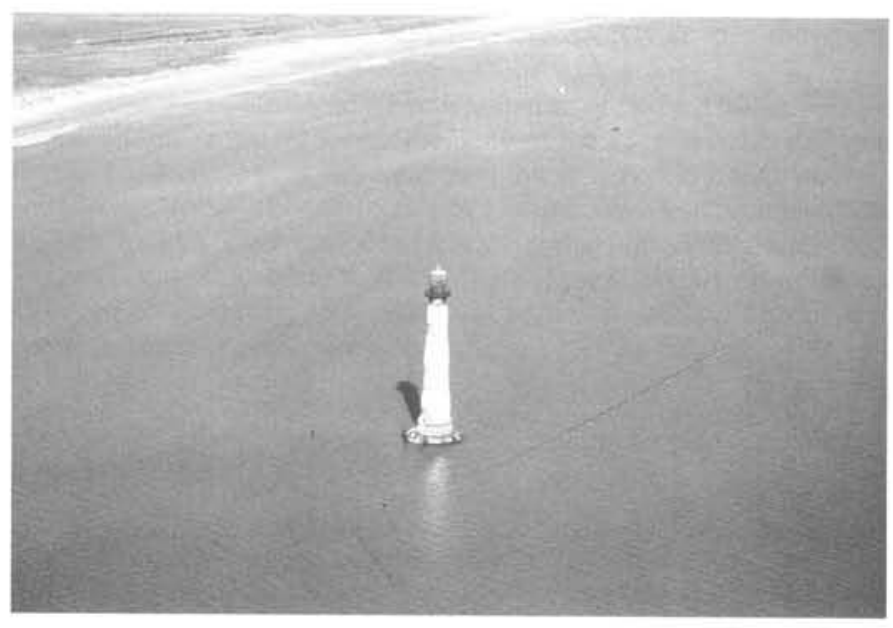

Figure 1.-Areal view of the Morris Island, South Carolina Lighthouse. The lighthouse was still on land in the 1940's. 


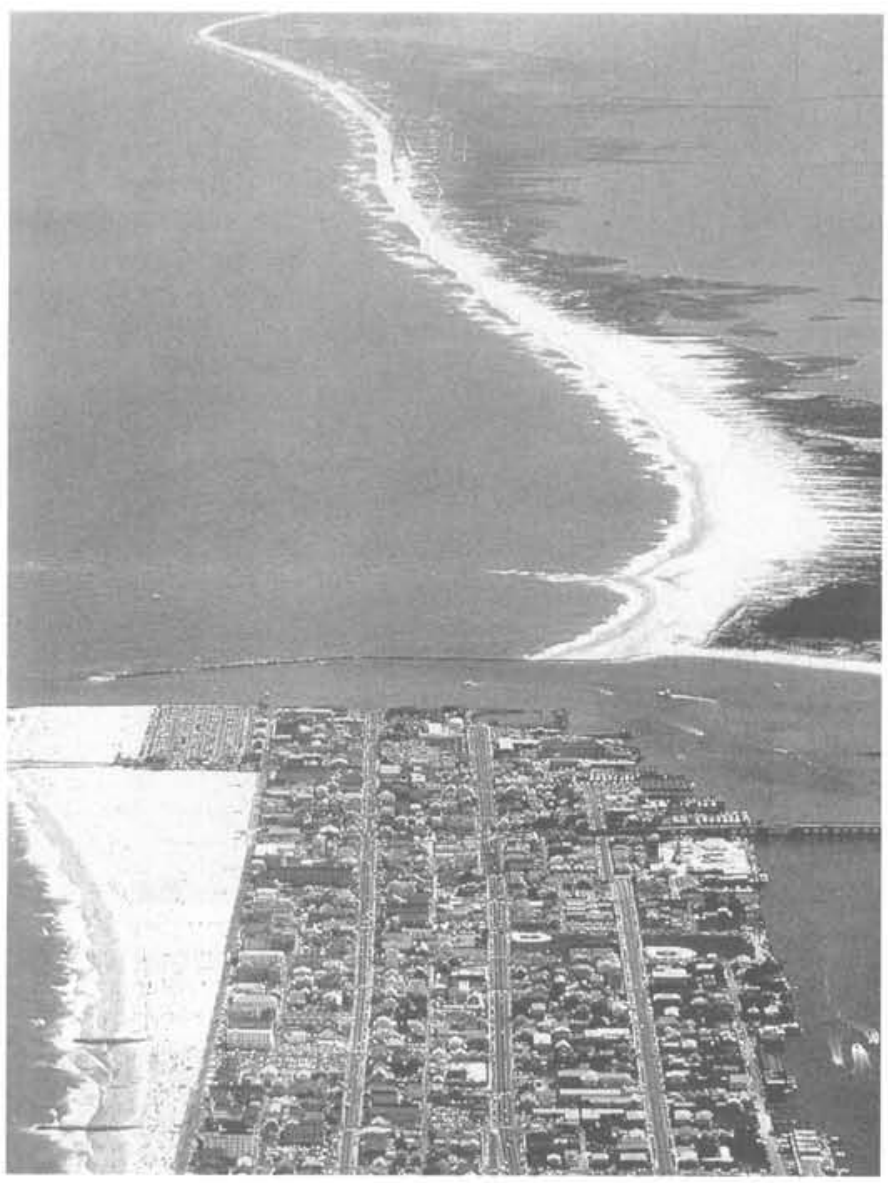

Figure 5.-The jetties at the south end of Ocean City, Maryland, shown here, are responsible for cutting off the sand supply to Assateague Island to the South (toward the top of photo). The jetties were constructed in 1933 when the islands were lined up with each other. Since 1933, the northern end of Assateague has migrated completely away from its former location, and its surf zone is now behind the former lagoon shoreline.

The literature (see review in Carter, 1988) is also voluminous on the subject of projected sea-level rise owing to the expected melting of the West Antarctic Ice Sheet caused by the greenhouse effect. The nature and complexity of the models used to predict greenhouseeffect sea-level changes (Barth and Titus, 1984) are beyond the scope of this paper. Predicted eustatic sea-level rise by the year 2100 ranges from 0.5 to $2 \mathrm{~m}$ above the present sea level.

From the geologic hazard standpoint, the most important research question is predicting the effect of sea-level rise on shorelineretreat rates. The problem is a complex one (Pilkey and Davis, 1987) and standard engineering models such as the Bruun rule are too rigid and are based on too many narrow assumptions to have wide application.

If the sea level rises $10 \mathrm{~m}$ in the next year, the shoreline would be at the $10 \mathrm{~m}$ contour interval. But if the level of the sea rises $2 \mathrm{~m}$ in the next $200 \mathrm{yr}$, the problem of shoreline location and retreat rate becomes much more complex. Endangered coastal communities need accurate predictions of shoreline position on a decades timeframe; a most difficult task.

There is a strong possibility that, if the higher prediction scenarios of sea-level rise due to the greenhouse effect come to be, our society will not be worrying about shorefront-recreation communities on the East and Gulf coasts. Instead, concern and funding will focus on the fate of Galveston, Texas; Miami, Florida; Charleston, South Carolina; Manhattan, New York; and other major cities.

\section{Sand Supply}

Each shoreline reach has a unique combination of sand sources. The major sources include rivers, eroding bluffs and cliffs, and the continental shelf. Locally, longshore transport of material from an adjacent shoreline segment may be important. The continental shelf contribution, via the landward pushing action of fair-weather waves, is the most difficult to determine. In most analyses, the continental shelf contribution is assumed to be the amount that cannot be accounted for from other sources.

The contribution to the erosion problem by the activities of man has been increasing dramatically in recent decades. Damming of rivers is cutting off a major source of beach sand in California. Seawalling of coasts, a very extensive process on European shores (Walker, H.J., 1988) has cut off the supply of sand normally contributed to the beaches by eroding bluffs. The myriad groins, seawalls, breakwaters, and jetties that line developed shorelines everywhere divert offshore, slowdown, trap, and otherwise reduce the regional beach sediment supply and hence increase erosion rates.

A spectacular example of the negative role of jetties on beach sand supply is afforded by the northern end of Assateague Island, Maryland (fig. 5). The jetties were constructed shortly after the inlet opened during the 1933 hurricane. Since that time, the loss of sand accumulating in front of Ocean City to the north has caused the shoreline to retreat and the island to migrate completely landward of the 1933 surf zone. Prior to 1933, there was no shoreline offset; the two islands were one and the same.

The prognosis is for an accelerating decrease in sediment supply to most of the developed beaches of the world.

\section{Wave Energy}

Storms cause the most visible and obvious shoreline retreat, but often storm-caused erosion is substantially "repaired" by poststorm onshore transportation of sediment. Different shorelines are adjusted to different wave climates. New England shorelines are subjected to frequent northeastern storms on an annual basis. The erosion rate of Florida's Gulf of Mexico beaches, on the other hand, is most affected by hurricanes spaced decades apart.

The most intriguing questions about the impact of waves and wave climate on future shoreline retreat involve an anticipated change in storm climate owing to the greenhouse effect. Both frequency and intensity of Atlantic hurricanes are predicted to increase. This will impact Gulf of Mexico-shoreline retreat rates more than those on the U.S. East Coast, where northeastern storms tend to be the more important shoreline erosion event.

\section{Solutions to the erosion problem}

The basic problem with responding to the shoreline erosion crisis is that two conflicting societal priorities come into play which cannot be simultaneously fulfilled. One priority is the preservation of shoreline property. In the U.S. such property is highly valued, and as a result it tends to be owned by influential individuals who are active in defense of their property. The second priority is preservation of the recreational beach. The beach is utilized and valued by numbers of people much larger than the numbers of property owners. But swimmers, surfers, fishermen, and beach walkers tend to be less vocal and 
less active in defense of beach preservation. If one beach is damaged in the process of saving houses, there is always another beach down the road.

The problem is illustrated by the lonely and underworked lifeguard on Myrtle Beach, South Carolina shown in fig. 6. This photo, taken at close to high tide, shows a very narrow, almost nonexistent beach in front of a seawall. The seawall, designed to protect buildings behind it, has been directly or indirectly responsible for the narrowing of the recreational beach. Was the price of beach loss worth protecting these buildings? Which is more important: buildings or beaches?

There are three main ways that our society can "solve" the beach erosion problem: (1) hard stabilization, (2) soft stabilization, and (3) relocation. Hard stabilization is any method of holding the shoreline in place using "hard" fixed objects. Soft stabilization is the emplacement of additional beach sand as a means of holding the shoreline in place. Relocation is the moving of threatened structures back as the shoreline retreats.

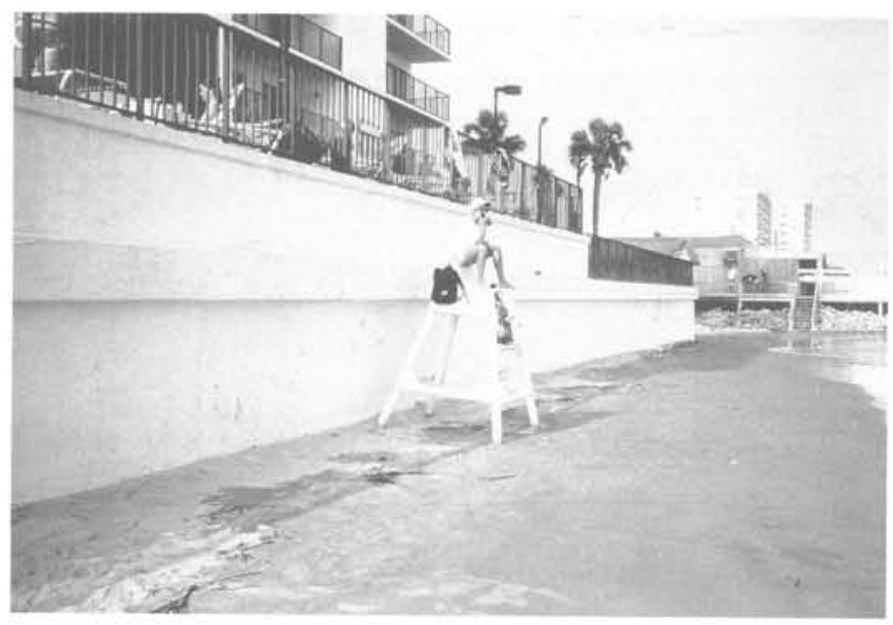

Figure 6.-A lifeguard on the beach at Myrtle Beach, South Carolina. The lifeguard has very little beach to patrol, thanks to the presence of the seawall that has narrowed the beach considerably.

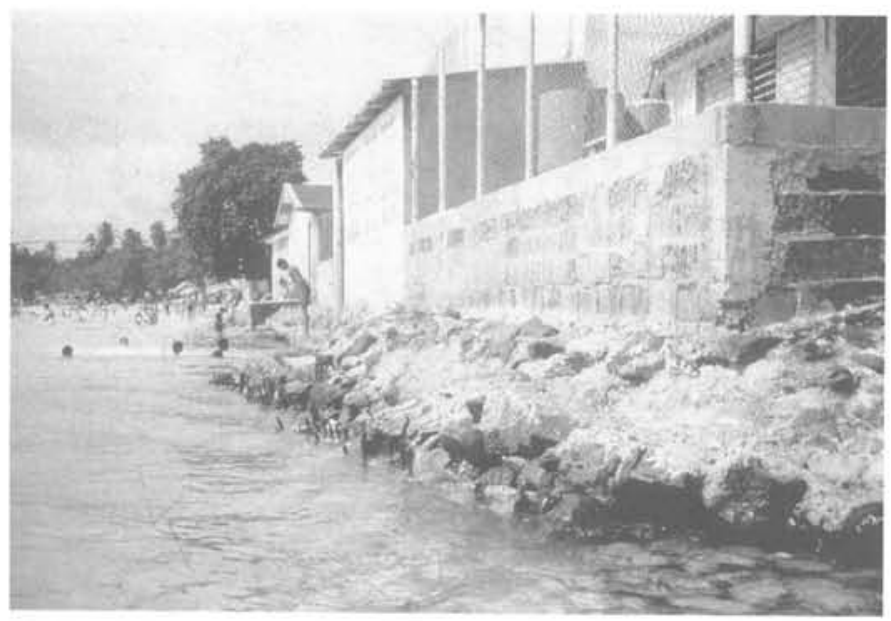

Figure 7.-A seawall protecting the foundation of some buildings on the South shore of Puerto Rico has resulted in the elimination of the portion of recreational beach.

\section{Hard stabilization}

Hard stabilization structures can be divided into two types, those that block wave energy and those that trap sand. Seawalls, energy absorbing shore-parallel structures built on the subaerial beach, are the most common type of hard structure used worldwide. Shore-perpendicular groins and shore-parallel offshore breakwaters are designed to increase beach width by trapping sand.

Advantage:

1. Most dependable way to save property adjacent to the beach. Disadvantages:

1. Degradation of the recreational beach,

2. Costly,

3. Ugly, and

4. Makes beach access difficult.

Seawalls and related structures are said to degrade the beach for the following reasons (Pilkey and Wright, 1988):

Seawall placement seaward of the high tide line. - On the day of seawall completion part or all of the recreational beach is missing. Seawall placement was responsible for much of the beach loss in Miami Beach prior to the 1980 beach replenishment project. The Sandbridge, Virginia, seawall, which was built in 1989, is a more recent example of beach degradation by this means.

Passive beach loss. - If a wall is placed on a shoreline that is retreating (which, of course, is usually the case), whatever is causing the retreat will continue to do so, and the beach will narrow up against the wall. Since most shorelines are eroding, seawalls will degrade most beaches through passive means. This is a long-term process (decades).

Active Beach loss. - This is beach front degradation caused by the direct impact of the wall on nearshore oceanographic processes. There is no disagreement about the fact that seawalls, where they extend into the surf zone, adversely affect the lateral transport of sand. More controversial is the question of how the wall actually affects the beach in front.

Kraus (1988) reviews the literature on seawall/beach interaction and concludes that walled and unwalled beaches exhibit similar beach changes. Kraus' review is mainly concerned with events (storm response). It is difficult to extrapolate the decades long phenomenon of beach degradation in front of walls from the observation of single storm events.

There is little doubt among coastal geologists that seawalls are responsible for beach degradation. Apparently doubts remain in the coastal engineering community as indicated by the following statement from the U.S. National Academy of Engineering (National Research Council, 1990). "Properly engineered seawalls and revetments can protect the land behind them without causing adverse effects to the fronting beaches." This statement is a surprising one since, judging from the engineering literature, there is no apparent disagreement over the validity of the passive role of seawalls in beach degradation (for example, Pilkey and Wright, 1988; Tait and Griggs, 1990). The statement is a good illustration of the depth of philosophical disagreement that exists between engineers and scientists over the long-term impact of seawalls.

Figure 7 shows a crude seawall protecting the foundations of some small buildings on a recreational beach along the south shore of Puerto Rico. This example clearly illustrates the basis of growing public concern over beach degradation (whatever the mechanism) by hard stabilization. Here, in Puerto Rico, an important recreational beach has been strongly degraded in order to save a few low-cost buildings.

Of course all buildings protected from shoreline erosion are not small and low cost. Needless to say the public dilemma over the question of which should be preserved, buildings or beach, deepens considerably when 20 -story beachfront condominiums are involved. 


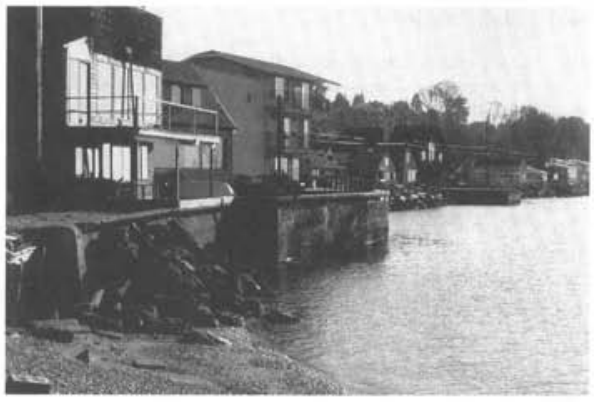

Figure 8.-A view of a beachless Seattle, Washington, (Puget Sound) shoreline. Here because of cold water temperatures, swimming is a relatively unimportant activity, and the beach loss related to seawall emplacement may not be critical from the public's viewpoint.

Beaches may have different values to our society in different locations, which can result in a different view of hard stabilization. In Seattle, Washington, bordering Puget Sound, there are a number of examples of narrow to nonexistent beaches fronting seawalls (for example, fig. 8). Public indignation over these seems minimal, perhaps because the beaches are not heavily used for swimming because of cold water temperatures.

\section{Beach Replenishment}

Advantages:

1. "Improves" the beach and

2. Protects buildings while in place,

Disadvantages:

1. Costly and

2. Temporary,

Beach replenishment is the emplacement of "new" sand to rebuild beaches that have retreated close to seawalls or to buildings. Sand is usually pumped to the beach from inlets, tidal delta shoals, or the continental shelf. In some cases, sand is trucked in from inland quarries.

The life span of replenished beaches is highly variable. Miami Beach, a $16-\mathrm{km}-$ long, $\$ 60-$ million, artificial beach, is largely in place after $10 \mathrm{yr}$. On the other hand, a 1982, \$5-million beach in Ocean City disappeared in a little more than 2 mo.

Figure 9 and 10 are before and after views of Wrightsville Beach, North Carolina, one of the most extensively replenished (more than 10 times) beaches in the U.S. Figure 9 shows the beach shortly after a new beach has been emplaced. Note the continuous dune of uniform height, distinguishable from its natural counterpart by the lack of dune gaps. Figure 10 shows the beach, $3 \mathrm{yr}$ after replenishment.

There are strong regional differences in beach life span along the U.S. East Coast barrier island shoreline (Pilkey 1988). East Coast Florida beaches south of Cape Canaveral typically last $7 \mathrm{yr}$; north of Cape Canaveral, 5 yr: Georgia through Delaware, $2-4 \mathrm{yr}$; and New Jersey, less than $2 \mathrm{yr}$. The minimum cost of a replenished beach capable of reducing the impact of a hurricane ranges from $\$ 1$ million up to $\$ 10$ million per mile. The replenishment alternative is a very costly one (Pilkey and Clayton, 1987). It could cost $\$ 2$ billion per decade to replenish the entire New Jersey developed shoreline and perhaps \$200 million per decade for the South Carolina developed shore.

Mathematical models used to predict beach behavior have routinely failed. This is because of a lack of understanding of the principles of nearshore oceanography, especially as far as storm processes are concerned. One cannot model what is not understood. There is also a tendency to accept storms as accidents, which greatly weakens applications of the models.

There is even a great difference of opinion as to the life span of a beach once it is emplaced. This is because: (1) Replenished beaches disappear at varying rates along their lengths making it possible to choose different locations from which to interpret life spans, and (2) frequently, it is assumed that sand removed from the subaerial beach is residing just offshore, still having a favorable dampening impact on storm waves. The offshore fate of replenished sand has yet to be studied. From the community standpoint, however, an underwater beach has little credibility.

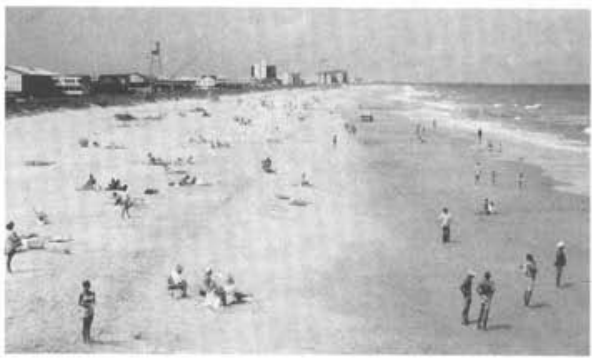

Figure 9,-Wrightsville Beach, North Carolina, immediately after a major beach replenishment project. Almost the entire beach shown here is an artificial one. The continuous dune line, level and without overwash gaps, does not have the appearance of natural dunes.

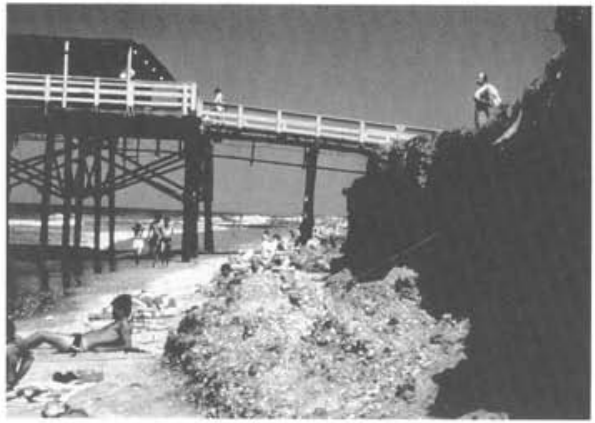

Figure 10.-Wrightsville Beach, North Carolina 3 yr after a beach replenishment project. 


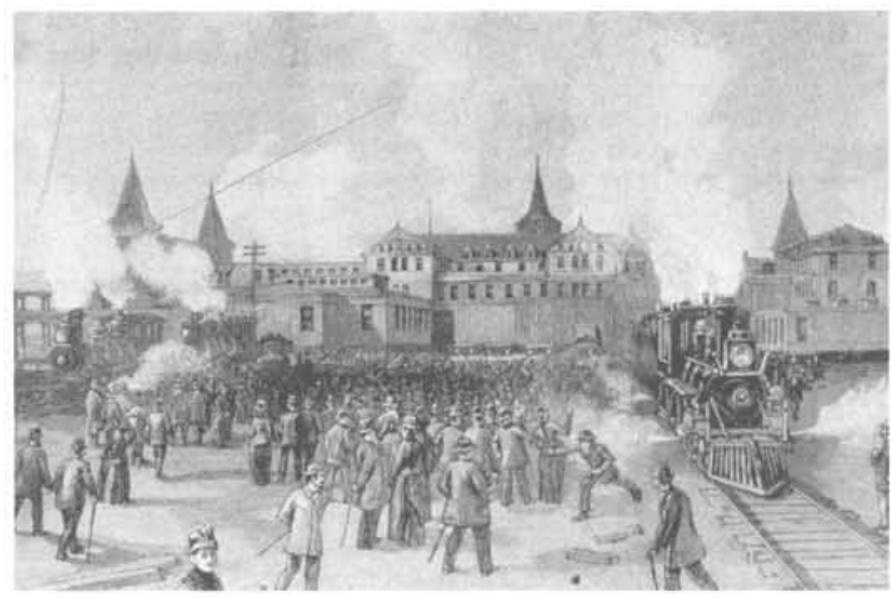

Figure 11.-Moving the Brighton Hotel on Coney Island, New York, back $600 \mathrm{~m}$ with the use of five steam locomotives in 1888 . Shoreline erosion forced the move. Drawing from Harpers Weekly Magazine.

Clearly, the beach replenishment alternative to erosion mitigation is not for developing countries. The cost is just too great. In addition, if sea-level rise continues and accelerates, the price of holding the shoreline in place and preventing loss of property along sandy low-lying shorelines will likely become unacceptable even to more wealthy nations.

\section{Relocation}

Advantages:

1. Preserves the beach,

2. Saves shoreline stabilization costs, and

3. Preserves buildings.

Disadvantages:

1. Politically difficult,

2. Could be financially costly, and

3. Loss of land.

Relocation is the general term for any shoreline erosion response that does not involve shoreline stabilization. This could mean relocation of buildings, demolishing of buildings, or simply letting them fall in.

Prior to World War II and the advent of the bulldozer, the latter two approaches were generally taken on rapidly eroding shorelines and still are in developing countries. Occasionally, beachfront buildings were moved back along the U.S. East Coast as long ago as the mid 1800's. In Nags Head, North Carolina, the 120-yr-old Outlaw family cottage has been moved back five times, and now it is once again close to the surf zone. In 1888, the Brighton Hotel on Coney Island in New York City was moved back $600 \mathrm{~m}$ with the aid of five steam locomotives (fig. 11). The move was made because of shoreline erosion.

\section{The future}

Coastal erosion promises to be an increasingly visible geologic hazard as sea level rises and the rush of development to the shore continues worldwide. Response to the problem will vary dramatically. Japan and Holland intend to suffer no land loss. In fact,
Holland continues to increase its land area at the expense of the area of the sea floor. Four U.S. states (New Jersey, North Carolina, South Carolina, and Maine) have now opted for the retreat option and have declared future hard stabilization illegal.

Considering the change in public perception of the value of beaches and the buildings-versus-beaches controversy, it is very likely that future erosion strategies will tilt in favor of responses that will allow preservation of beaches. What society needs now from the scientific and engineering community is an accurate basis for developing long-term coastal erosion strategies. Most important, is the means of predicting the impact of sea-level rise on shoreline retreat.

\section{References}

Barth, M.C., and Titus, J.G., 1984, Greenhouse Effect and Sea Level Rise: New York, Van Nostrand Co., 322 p.

Bird, E.C.F., 1985, Coastline Changes-A Global Review: Norwich, John Wiley, $219 \mathrm{p}$.

Carter, R.W.G., 1988, Coastal Environments: New York, Academic Press, $617 \mathrm{p}$.

Devoy, R.J.N., 1987, Sea Surface Studies-A Global View: New York, Croom Helm, 649 p.

Dolan, R., Anders, F., and Kimball, S., 1988, Coastal Erosion and Accretion-National Atlas of the United States: Reston, Virginia, U.S. Geological Survey, 1 sheet.

Kraus, N., 1988, The effects of seawalls on the beach-an extended literature review, in Kraus, N.C., and Pilkey, O.H., eds., The effects of seawalls on the beach: Journal Coastal Research Special Issue 44 . p. 1-28.

National Research Council, 1990, Managing Coastal Erosion: Washington, D.C., National Academy Press, 182 p.

Pilkey, O.H., 1988, A "Thumbnail Method" for beach communitiesestimation of long term beach replenishment requirements: Shore and Beach, v. 56, p. $23-31$.

Pilkey, O.H., and Clayton, T.P., 1987, Beach replenishment-the national solution: Charleston, South Carolina, American Society Civil Engineering Coastal Zone '87, p. 1408-1419.

Pilkey, O.H., and Davis, T., 1987, An Analysis of coastal recession models - North Carolina Coast, in Nummedal, D., Pilkey, O., and Howard, J., eds., Sea Level Fluctuation and Coastal Evolution: Society of Economic Paleontologists and Mineralogists Special Publication 44. p. 59-68.

Pilkey, O.H., and Wright, H., 1988, Seawalls versus beaches, in Kraus, N.C., and Pilkey, O.H., eds., The effects of seawalls on the beach: Journal Coastal Research Special issue 4, p. 41-64.

Tait and Griggs, 1990, Beach response to the presence of a seawall: Shore and Beach, April, p. 11-28.

Walker, H.J., 1988, Artificial structures and shorelines: Dordrecht, The Netherlands, Kluwer Academic Publishers, 708 p.

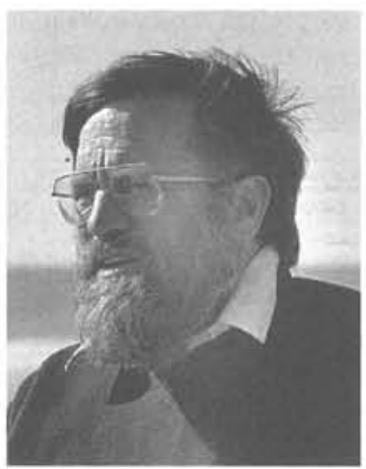

Orrin Pilkey is a James B. Duke Professor at Duke University in Durham, North Carolina where he directs the Program for the Study of Developed Shorelines. He is the former editor of the Journal of Sedimentary Petrology and recipient of the Francis Sheppard Medal in Marine Geology. Although originally a deep-sea sedimentologist, he now specializes in coastal geology. Pilkey and associates have recently completed extensive studies of the U.S. beach replenishment experience and the impact of seawalls on recreational beaches. 